\title{
Implementing the Stockholm Treaty on Persistent Organic Pollutants
}

\section{Porta, E Zumeta}

\section{Implementation of the Stockholm Treaty on Persistent Organic Pollutants is a unique opportunity to foster changes in environmental, occupational, and food policies}

e

$\mathrm{n}$ the forthcoming months many scientific, technical, and political energies will be devoted throughout the world to design specific plans to implement the Stockholm Treaty on Persistent Organic Pollutants (POPs). ${ }^{1-4}$ Drawn under the leadership of the United Nations Environment Programme (UNEP) —with significant contributions from nongovernmental organisations, trade unions, and private companies-it has been saluted as "a global public health treaty", one that will "protect public health both from DDT and malaria", "the first global agreement ever to seek to ban an entire class of chemicals because of their direct effects on human health". ${ }^{34}$

After four years of work, in December 2000 this "international legally binding instrument" was finalised. In May 2001 delegates from over one hundred countries (including the United States, Canada, and all members of the European Union) signed the accord in Stockholm. It is expected to be put into effect by 2004 , after 50 nations have ratified it (so far, eight countries have done so). Meanwhile, governments can facilitate voluntary implementation of the agreement prior to its entry into force.

Implementation of the treaty at all population levels (municipal, regional, continental) constitutes a fantastic opportunity to foster changes in environmental, occupational, public health, and food policies. But the challenges are immense.

\section{THE ANNEXES AND NATIONAL IMPLEMENTATION PLANS}

The substances covered by the treaty are eight pesticides (aldrin, chlordane, DDT, dieldrin, endrin, heptachlor, mirex, and toxaphene), two industrial chemicals (hexachlorobenzene (HCB) and polychlorinated biphenyls (PCBs)), and two POP by-products (dioxins and furans). ${ }^{12}$ The first 10 compounds, except DDT, are included in Annex A (elimination): the aim is to cease their production, use, and trade. The agreement prohibits production of PCBs immediately, and requires countries to remove from use all equipment containing PCBs, which should be phased out in the next quarter century or so. Annex B (restriction) deals with DDT: its use is accepted for the purpose of disease vector control, and as intermediate in the production of dicofol; countries that have requested to do so are allowed to continue using DDT against malaria, until effective and affordable alternatives are available. Annex C (unintentional production) addresses the release reduction of the unintentional production by anthropogenic sources of polychlorinated dibenzo- $p$-dioxins (PCDDs), polychlorinated dibenzofurans (PCDFs), HCB, and PCBs. ${ }^{12}$ During the treaty negotiations, hexachlorocyclohexane ( $\mathrm{HCH})$, chlordecone, hexabromobiphenyl, polycyclic aromatic hydrocarbons (PAHs), and other substances with characteristics similar to the dozen POPs included were also promoted for inclusion in the treaty by several European countries, but were finally excluded. ${ }^{2}$

Although some countries were initially reluctant to agree, the treaty was finally conceived as a dynamic legal instrument; for instance, it makes provision for new substances with POP characteristics to be included in the future. It also adopts a precautionary "approach" to include additional POPs in Annexes A, B, or C. ${ }^{2}$ Calls have been made for polybrominated biphenyls (PBBs), chlordecone, hexachlorocyclohexanes, hexabromobiphenyl, and PAHs, among others, to be included in the treaty.

Developed countries will have to provide funds and technical assistance to less developed nations, so that the latter can take effective measures. The European Commission seems committed to providing technical and financial assistance to developing countries and countries with economies in transition. Canada has pioneered a contribution of \$200 000 to China to reduce the use and dispersion of POPs. China and India are still producing DDT. ${ }^{5}$ Even if they ratify the treaty, it is unclear at what pace they will implement it.

Also remarkable is that each party to the Stockholm Convention is required to develop a national implementation plan (NIP) describing how it will meet the obligations set by the agreement. Governments must develop NIPs within two years from its entry into force. The NIP should supply a framework to implement, in a systematic and participatory way, priority policy and regulatory reform, capacity building, and investment programmes.

Developing countries and countries with economies in transition are eligible for capacity building support for the implementation of the NIP. ${ }^{1}$ Financing for these plans is available through the Global Environment Facility. The GEF has established some guidelines for enabling activities for the Stockholm Convention, and has approved the project "Development of National Implementation Plans for the Management of POPs", the objective of which is to strengthen national capacity to manage POPs and to apply the Convention.

\section{KNOWLEDGE BASE AND SOCIAL AGENDAS}

POPs travel great distances: both across the atmosphere and through international trade channels. They can only be degraded slowly, and thus they persist in the environment, biodegrade, and accumulate in organisms. They also accumulate in the cultural environment and in the social organisation: POPs are deeply rooted in our way of life; we will come back to this later.

Virtually all humans store POPs in fat tissues, in particular p,p-dichlorodiphenyldichloroethane (DDE), the most predominant PCBs (such as congeners $138,153,180,187,170$, or 118$), \mathrm{HCH}$, and HCB. ${ }^{6-10}$ From womb to tomb, exposure occurs largely through a wide variety of foods ${ }^{11}$; mostly, from the fatty components of animal foods, including recycled animal fats from slaughterhouses, which are used as components of many food products and animal feed ingredients. ${ }^{12-14}$ Applying effective measures to decrease POP contamination of animal feed and human foods is a major challenge. The existing legislation on chemical residues in food is unevenly enforced in Europe.

A knowledge base already exists on the low dose, long term, indirect biological effects of POPs; for instance, on their developmental and neurological effects, hormonal and immunological disruption, or cancer promotion. ${ }^{461015}{ }^{16}$ However, for most POPs the evidence is still too weak to confidently conclude, with a population

Abbreviations: ECA, environmental chemical agent; $\mathrm{HCB}$, hexachlorobenzene; $\mathrm{HCH}$, hexachlorocyclohexane; NIP, national implementation plan; $\mathrm{PAH}$, polycyclic aromatic hydrocarbon; PBB, polybrominated biphenyl; PCB, polychlorinated biphenyl; PCDD, polychlorinated dibenzo-p-dioxin; PCDF, polychlorinated dibenzofuran; POP, persisten organic pollutant 
perspective, that they cause a high proportion of the burden of suffering associated with problems such as infertility, congenital defects, learning disabilities, tremors, Parkinson's disease, diabetes, or cancer. Scientific uncertainties on the effects of POPs are abundant. These uncertainties are partly caused by the fact that we are frequently exposed to POP mixtures; such mixtures bioaccumulate in our bodies, yet the physiological and clinical effects of mixtures have seldom been analysed. ${ }^{610}$ Furthermore, most POPs interact with other environmental agents and with endogenous factors. It is therefore difficult to study the predominantly indirect, weak causal effects of POPs. However, if research on POPs and other environmental chemical agents (ECAs) becomes a stronger social priority, biological, clinical, and epidemiological evidence on their effects will rapidly accrue. A major scientific and social challenge will then be to properly assess the clinical and social significance of new findings on POP behaviour and effects.

Knowledge gaps abound. In many regions of the world information on POPs follows a downward gradient. Firstly, large data gaps exist on POP contamination of the environment - that is, in soils and waters (even many areas of Europe lack systematic surveys). Secondly, gaps also exist on food and feed contamination (not all municipal and regional public health systems have comprehensive, continuous surveillance programmes in place, and the capacity to detect accidental contaminations is weak in some areas). Thirdly, very few countries regularly conduct representative surveys of concentrations of POPs and other ECAs in the general population. Finally, a proportionally small fraction of studies have analysed POP effects on humans.

The Stockholm Convention is only one component of the global POP elimination process. Other elements of this process include the UNEP London Guidelines for the Exchange of Information on Chemicals in International Trade, the Rotterdam Convention on prior informed consent, the Basel Convention on transboundary movement of hazardous substances, the Protocol to the London Convention on ocean dumping, Agenda 21 (chapter 19), or the Aarhus Protocol, among others. ${ }^{2}$ Within the European Union, several initiatives with a potential impact on POPs are underway, including the White Paper on the Strategy for a Future Chemicals Policy. ${ }^{17}$

Difficulties of implementing the treaty are abundant; they concern, for instance, technologies to eliminate POPs without creating other POPs (such as when incineration of PCBs yields by-products like dioxins and furans).

If technical and sociopolitical efforts for capacity building related to the implementation of the agreement are successful, if government agencies and private parties work together, if international economic organisations cooperate ... then some exposures to POPs will cease soon. Yet others-including exposure to POP residues-will continue for decades. Given their long half lives, we aim for POPs not to be detected in the cord blood of the children of our grandchildren. That would seem a target, or a dream, attractive enough. $^{18}$

However, there is one additional barrier for effective action: the general public is mostly unaware or uncertain about the reasons for and the costs of addressing POP contamination. Often, POP effects are but a blurry silhouette in the social imagery. With few exceptions, the structural changes needed to control POPs-changes in industrial, agricultural, environmental, public health, and food policies-are not very high on the social agendas. The results of many elections in Europe and elsewhere indicate that this is so. Thus, a great deal of scientific pedagogy and political will is required to implement the treaty. But even those efforts will not suffice: pure reliance on science and politics would reflect a somewhat naive and technocratic attitude, ill suited to the globalised and interdependent world we have, and inappropriate to the the global and multidimensional problems posed by POPs. Many citizens, cities, regions, and corporations will prefer POP matters to remain as they now stand. Conversely, if things are to improve, much individual and collective behaviour will need to change. Important components of local and international economic structures will need to be mended or removed. How could any of this be achieved unless we know more about and connect better with the desires and nightmares of our fellow citizens? The Stockholm Treaty should not be looked only as a legal, political, and technical instrument: it should also become a collective aspiration, a common dream. While parliaments throughout the world examine plans to implement the treaty, its pros and cons must be discussed with citizens, and we must listen. Then, perhaps, a crisp and enticing dream will emergeshared, realistic, more feasible.

\section{ACKNOWLEDGEMENT}

We are grateful to Estefanía Blount for scientific advice, and to David J MacFarlane, Olga Juan, and Puri Barbas for technical help.

Occup Environ Med 2002;59:651-653

\section{Authors' affiliations}

M Porta, E Zumeta, Institut Municipal d'Investigació Mèdica, Universitat Autònoma de Barcelona, Spain

Correspondence to: Prof. Miquel Porta, Institut Municipal d'Investigació Mèdica, Universitat Autònoma de Barcelona, Carrer del Dr Aiguader 80, E-08003 Barcelona, Spain; mporta@imim.es

\section{REFERENCES}

1 United Nations Environment Programme. Stockholm Convention on Persistent Organic Pollutants (POPs). Available at: http://irptc.unep.ch/pops and: http://www.chem.unep.ch/sc/ (last accessed 14 June 2002)

2 Karlaganis G, Marioni R, Sieber I, et al. The elaboration of the "Stockholm Convention" on persistent organic pollutants (POPs): a negotiation process fraught with obstacles and opportunities. Environ Sci Pollut Res Int 2001;8:216-21.

3 International POPs Elimination Network. POPs: the birth of a public health treaty. Available at: http://www.ipen.org/ treaty02.html (last accessed 27 February 2002).

4 Physicians for Social Responsibility. Environmental endocrine disruptors. What health care providers should know. Available at: http://www.psrus.org/enddisprimer.pdf. Frequently asked questions about endocrine disruptors. http://www.psrus.org/endofs.htm. International effort would phase out 12 toxins. http://www.psrus.org/popsmonitor.pdf (all last accessed: 27 February 2002).

5 Liroff $\mathbf{R}$. Reduction and elimination of DDT should proceed slowly. BM 2000;321:1404-5.

6 Hansen LG. Stepping backward to improve assessment of PCB congener toxicities. Environ Health Perspect 1998;106(suppl 1): 171-89.

7 DeVoto E, Kohlmeier L, Heeschen W. Some dietary predictors of plasma organochlorine concentrations in an elderly German population. Arch Environ Health 1998;53:147-55.

8 Liem AK, Furst P, Rappe C. Exposure of populations to dioxins and related compounds. Food Addit Contam 2000;17:241-59.

9 Sanz-Gallardo I, Guallar E, van'ł Veer P, et al. Determinants of p,p-dichlorodiphenyldichloroethane (DDE) concentration in adipose tissue in women from five European cities. Arch Environ Health 1999;54:277-83.

10 Porta M, Kogevinas M, Zumeta $E$, et al. Concentraciones de compuestos tóxicos persistentes en la población española: el rompecabezas sin piezas y la protección de la salud pública. Gac Sanit 2002; 16:257-66.

11 Schafer KS, Kegley SE. Persistent toxic chemicals in the food suply. J Epidemio Commun Health 2002;56. In press.

12 Schepens PJ, Covaci A, Jorens PG, et al. Surprising findings following a Belgian food contamination with PCBs and dioxins. Environ Health Perspect 2001;109:101-3.

13 van Larebeke $\mathbf{N}$, Hens L, Schepens $P$, et al. The Belgian PCB and dioxin incident of January-June 1999: exposure data and potential impact on health. Environ Health Perspect 2001;109:265-73.

14 Kalantzi OI, Thomas GO, Alcock RE, et al. The global distribution of PCBs and organochlorine pesticides in butter. Environ Sci Technol 2001;35:1013-18.

15 Brouwer A, Longnecker MP, Birnbaum LS, et al. Characterization of potential endocrine-related health effects at low-dose levels of exposure to PCBs. Environ Health Perspect 1999; 107(suppl 4):639-49

16 Cogliano VJ. Assessing the cancer risk from environmental PCBs. Environ Health Perspect 1998;106:317-23.

17 Commission of the European Communities. White Paper: Strategy for a future Chemicals Policy. COM (2001) 88 final. Brussels: Commission of the European Communities, 2001. Available at: http://europa.eu.int/comm/environment (last accessed 17 June 2002).

18 Porta M. Bovine spongiform encephalopathy, persistent organic pollutants and achievable utopias. J Epidemiol Community Health 2002;56. In press. 